\title{
Do the pollution related to high-traffic roads in urbanised areas pose a significant threat to the local population?
}

\author{
Joanna Kobza $(\mathbb{D}) \cdot$ Mariusz Geremek
}

Received: 24 August 2016/Accepted: 9 November 2016/Published online: 24 December 2016

(C) The Author(s) 2016. This article is published with open access at Springerlink.com

\begin{abstract}
Many large neighbourhoods are located near heavy-traffic roads; therefore, it is necessary to control the levels of air pollution near road exposure. The primary air pollutants emitted by motor vehicles are $\mathrm{CO}$, $\mathrm{NO}_{2}$ and $\mathrm{PM}$. Various investigations identify key health outcomes to be consistently associated with $\mathrm{NO}_{2}$ and $\mathrm{CO}$. The objective of this study was the measurementbased assessment for determining whether by hightraffic roads, such as motorways and express ways, and the concentrations of $\mathrm{CO}$ and $\mathrm{NO}_{2}$ are within normal limits and do not pose threat to the local population. Average daily values (arithmetic values calculated for 1$\mathrm{h}$ values within $24 \mathrm{~h}$ or less, depending on result availability) were measured for concentrations of $\mathrm{NO}_{2}$ and $\mathrm{CO}$ by automatic stations belonging to the Voivodship Environmental Protection Inspectorate in Katowice, in areas with similar dominant source of pollutant emission. The measurements were made in three sites: near the motorway and expressway, where the average daily traffic intensity is 100983 and 35414 of vehicles relatively. No evidence was found of exceeding average daily values equal to the maximum allowable $\mathrm{NO}_{2}$
\end{abstract}

J. Kobza $(\bowtie) \cdot$ M. Geremek

Public Health Department, School of Public Health, Medical University of Silesia in Katowice, Piekarska 18, 41-902 Bytom, Poland

e-mail: koga1@poczta.onet.pl concentration due to the protection of human health in the measurement area of the stations. No daily average values exceeding the admissible $\mathrm{CO}$ concentration $(8-\mathrm{h}$ moving average) were noted in the examined period. The results clearly show lack of hazards for general population health in terms of increased concentrations of $\mathrm{CO}$ and $\mathrm{NO}_{2}$ compounds that are closely related to high intensity car traffic found on selected motorways and speedways located near the city centres.

Keywords Traffic-related air pollution · Population health $\cdot$ Nitrogen dioxide $\cdot$ Carbon monoxide .

Environmental policy

\section{Introduction}

Air quality and its impact on health are major environmental health issues (WHO 2012). Vehicular exhaust has become a main source of air pollution in urbanised areas. The primary air pollutants emitted by motor vehicles are carbon monoxide $(\mathrm{CO})$, nitrogen oxides $\left(\mathrm{NO}_{\mathrm{x}}\right.$ including $\mathrm{NO}$ and $\mathrm{NO}_{2}$ ) and particulate matter (PM). Numerous epidemiological studies supported by some toxicological investigations demonstrate a positive association between $\mathrm{NO}_{2}$ and $\mathrm{CO}$ concentration and increased adverse respiratory and cardiovascular events, including morbidity and mortality (Anderson, 2009; Samoli et al., 2005; Ostro et al., 2009; Fenger, 2009; Bérard et al., 2015). Even short exposure to diesel 
exhaust fumes found in the air in concentrations that are typical of areas close to high-traffic roads, in urbanised areas, has an effect on vasoconstriction (narrowing of the lumen of vessels resulting from contraction of smooth muscular coat), thus leading to increased arterial blood pressure or to decreased local blood flow; what is also observed is increased rigidity of blood vessels as a result of concomitant atherosclerosis, increased blood clotting capability (through inhibition of fibrinolytic factor secretion) and myocardial ischaemia (Lucking et al., 2008, Lundbäck et al., 2009; Mills et al., 2007; Mills, 2005; Peretz et al., 2008). Increased $\mathrm{NO}_{2}$ level and presence of $\mathrm{PM}_{2.5}$ particles in the atmosphere may also be related to the risk of increased cholesterol level (Sørensen et al., 2015). Many hours of staying in places of residence located near high-traffic roads is connected with increased level of the AC133+ stem cells responsible for processes of blood vessel reparation, the presence of which in peripheral blood may be an early indicator of damage to the cardiovascular system (caused to a high extent by particles with $\mathrm{PM}_{2.5}$ diameter) (De Jarnett et al., 2015). Exposure to noise and air pollution may also lead to elevated peripheral blood pressure and increase the risk of cardiovascular diseases (Chang et al., 2015; Miller et al., 2015; Fecht et al., 2016). Constant remaining in locations situated near high-traffic roads is also connected with the risk of increased CRP (C-reactive protein) concentration in peripheral blood, which is an important risk factor of CVD (cardiovascular diseases) (Lanki et al., 2015). Part of studies showed a relationship between a long-lasting exposure of residents to increased $\mathrm{NO}_{2}$ level and death rate due to coronary artery disease (Gan et al., 2011). A correlation was also demonstrated between elevated $\mathrm{CO}$ concentration and increased number of admissions of adults due to CVD and of children due to respiratory diseases (Samoli et al., 2016). Based on the recent studies, elevated $\mathrm{CO}$ and $\mathrm{NO}_{2}$ concentrations have a considerable effect on the number of patients reporting to Emergency Departments in hospitals due to exacerbation of asthma (Zheng et al., 2015; Khamutian et al., 2015). Significantly increased levels of $\mathrm{NO}_{2}, \mathrm{CO}$ and $\mathrm{PM}_{2.5}$ particles in the atmosphere also lead to increased risk of premature births, possibility of hypertension in pregnant women and risk of preeclampsia (Pedersen et al., 2014; Männistö et al., 2015; Li et al., 2016; Qian et al., 2016).

Nitrogen oxides rank among the most dangerous compounds. They get into the atmosphere through human activity. They play a significant role in the formation of such adverse events as acid rains, winter smog and photochemical smog and indirectly - they act as a tropospheric ozone precursor. $\mathrm{NO}_{2}$ is a brutal gas with sharp odour. It is produced, for instance, as a result of nitrogen oxide (NO) oxidation. It is strongly toxic for the respiratory and immune systems in the human body. As a result of the oxidation of nitrogen found in the air and high temperatures occurring in the processes of combustion, nitrogen oxide is produced: $\mathrm{N}_{2}+\mathrm{O}_{2}=2$ NO. As the temperature drops, nitrogen oxide becomes nitrogen dioxide along the following formula: $2 \mathrm{NO}+$ $\mathrm{O}_{2}=2 \mathrm{NO}_{2}$, and is usually emitted into the atmosphere in this form. In the polluted atmosphere and under the influence of ozone or hydroxyl radical, $\mathrm{NO}_{2}$ oxidises to nitrogen acid $\left(\mathrm{HNO}_{3}\right)$. Ions produced as a result of nitrogen acid dissociation are the major acidifying compounds. Moreover, nitrogen ion $\mathrm{NO}_{3}$ - has a considerable effect on eutrophication of terrestrial and aqueous ecosystems. Nitrates produced upon binding with other compounds found in the atmosphere, e.g. ammonia, become an important factor facilitating the formation of the $\mathrm{PM}_{2.5}$ dust particles (Ekoportal, 2016; Government of Canada, 2010).

Carbon oxide is an inflammable gas, where carbon occurs in the 2 nd oxidation degree. In the atmosphere, it oxidises to $\mathrm{CO}_{2}$, which results in the production of ozone. $\mathrm{CO}$ is a colourless and odourless gas strongly toxic for the human body, which-due to low specific gravity-spreads in the atmospheric air quickly. The main source of $\mathrm{CO}$ emission is road transport, petrol engine-driven vehicles in particular. Anthropogenic emission is first of all caused by fuel combustion processes- $\mathrm{CO}$ is produced upon incomplete combustion of carbon. The volume of emission depends on the type of vehicle, its speed and operating principle (Ekoportal, 2016). In concentration higher than $5000 \mathrm{ppm}$, its adverse effect on the human body is evident. 
Aim

The objective of this study was the measurement-based assessment for determining whether by high-traffic roads, such as motorways and express ways, the concentrations of $\mathrm{CO}$ and $\mathrm{NO}_{2}$ are within normal limits and do not pose threat to the local population.

\section{Methodology}

The concentrations of $\mathrm{CO}$ and $\mathrm{NO}_{2}$ in air were measured. The data used in this study were obtained from three automatic stations of the State Environmental Monitoring in the Silesian Voivodship (Upper Silesian urban area), with dominant source of pollutant emission with car communication background. The measurements were made in years 2007-2014 in three sites: Chorzów Batory, near the A4 motorway (longitude $18^{\circ} 56^{\prime} 15^{\prime \prime}$ E, latitude $50^{\circ} 15^{\prime} 15^{\prime \prime} \mathrm{N}$ ); Katowice at Górnośląska Avenue (longitude 19¹'10.20" E, latitude $\left.50^{\circ} 14^{\prime} 48.50^{\prime \prime} \mathrm{N}\right)$ and Częstochowa at Armii Krajowej

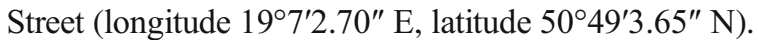
All measurement stations belong to the Voivodship Environmental Protection Inspectorate (VEPI) in Katowice. Average daily values (arithmetic values calculated for 1-h values within $24 \mathrm{~h}$ or less) were measured for concentrations of $\mathrm{NO}_{2}$ and $\mathrm{CO}$. Although analysed $\mathrm{NO}_{2}$ and $\mathrm{CO}$ concentrations within $24 \mathrm{~h}$ show asymmetry, the studies employed the arithmetic average as this is the only average measure (for $\mathrm{CO}$, arithmetic moving average for the interval of $8 \mathrm{~h}$ ) calculated in the analysis of air pollutant concentrations. Additionally, an analysis was conducted of 1-h values of $\mathrm{NO}_{2}$ and maximal 8-h averages - from among moving averages-for $\mathrm{CO}$ in the relevant periods of time so as to assess the statistical probability of the studied air pollutant concentrations being higher than maximum allowable, due to protection of human health. The statistical analyses were performed by means of Stat Soft, Inc. (2011) STATISTICA version 10 , whereas other calculations were carried out using the Microsoft Excel 2010 spreadsheet. The dependence was studied with correlation coefficient $\gamma$ in ordinal scale and with Kendall rank correlation coefficient $\tau(\tau \mathrm{K})$ in ratio scale. A correlation between classes of air index and years for selected measurement stations was analysed with Cramer's V. Empirical distribution of $\mathrm{NO}_{2}$ and $\mathrm{CO}$ concentrations in the studied periods of time were surveyed with association (contingency) tables or with use of graphic form, i.e. categorised histograms. Changes in the largest values of arithmetic average of $\mathrm{NO}_{2}$ and $\mathrm{CO}$ concentrations in the studied periods of time, in particular months, were shown with charts with polar coordinates (radar charts), where months in consecutive studied years were determined with a triangle while values of air pollutant concentrations were reflected by the distance from the centre (beginning) of the coordinate system.

\section{Results}

Common air quality index

The analysis of air quality in the world uses many indicators. One of those is CAQI (Common Air Quality Index), which is used for classification and comparison of air quality in European Union states. It is also employed by the EEA (European Environmental Agency) to provide information on the environment. The comparison of air quality in selected cities is based on two categories of measurement stations: communication stations and urban background stations. CAQI is calculated for three basic pollutants: $\mathrm{PM}_{10}, \mathrm{NO}_{2}, \mathrm{O}_{3}$ and, additionally, for $\mathrm{PM}_{2,5}, \mathrm{CO}$ and $\mathrm{SO}_{2}$. The above air quality index has got five categories (classes, levels). Classes 1 to 3 reflect satisfactory air quality, i.e. the air pollution level that does not pose threat to human health, while Classes 4 and 5 reflect bad air quality, i.e. the air pollution level that does pose threat to human health, particularly in the so-called high-risk groups (Class 4 ) or the general population (Class 5) (Table 1).

\section{National and European policy}

In Poland, the maximum allowable level of average annual concentration of $\mathrm{NO}_{2}$ is $40 \mu \mathrm{g} / \mathrm{m}^{3}$ while the maximum allowable level of annual $1-\mathrm{h}$ concentration is $200 \mu \mathrm{g} / \mathrm{m}^{3}$. This level can be exceeded up to 18 times per year. The alarm level of average $1-\mathrm{h}$ concentration is $200 \mu \mathrm{g} / \mathrm{m}^{3}$ (Journal of Laws 2002a, No. 87, item 796). 
Table 1 Recommended actions in case of occurrence of the given air quality index class, based on the U.S. Environmental Protection Agency (EPA) recommendations

\begin{tabular}{|c|c|c|c|}
\hline $\begin{array}{l}\text { Air quality } \\
\text { index/classes }\end{array}$ & $\begin{array}{l}\text { Air } \\
\text { pollution } \\
\text { level }\end{array}$ & $\begin{array}{l}\text { General } \\
\text { population }\end{array}$ & $\begin{array}{l}\text { High-risk } \\
\text { population }\end{array}$ \\
\hline $\begin{array}{l}\text { Class } 1 \\
\text { Class } 2\end{array}$ & $\begin{array}{l}\text { Very low } \\
\text { Low }\end{array}$ & $\begin{array}{l}\text { Satisfactory air } \\
\text { quality, no or } \\
\text { low health risk } \\
\text { due to air } \\
\text { pollution. It is } \\
\text { possible to stay } \\
\text { and perform } \\
\text { any activities } \\
\text { outdoors }\end{array}$ & $\begin{array}{l}\text { Satisfactory air } \\
\text { quality, no or } \\
\text { low health risk } \\
\text { due to air } \\
\text { pollution. It is } \\
\text { possible to stay } \\
\text { and perform } \\
\text { any activities } \\
\text { outdoors }\end{array}$ \\
\hline
\end{tabular}

Class 3 Average The regular tasks It is necessary to outdoors do not consider have to be decrease or changed distribution of outdoor activity over time if it requires longterm or intensified effort, especially in case of any aggravated health condition symptoms

\begin{tabular}{|c|c|c|c|}
\hline Class 4 & High & $\begin{array}{l}\text { It is necessary to } \\
\text { consider } \\
\text { decrease or } \\
\text { distribution of } \\
\text { outdoor activity } \\
\text { over time if it } \\
\text { requires long- } \\
\text { term or intensi- } \\
\text { fied effort }\end{array}$ & $\begin{array}{l}\text { Outdoor activity } \\
\text { which requires } \\
\text { long-term or in- } \\
\text { tensified effort } \\
\text { must be limited } \\
\text { and it is neces- } \\
\text { sary to consider } \\
\text { leaving chil- } \\
\text { dren, elderly } \\
\text { persons, preg- } \\
\text { nant women } \\
\text { and persons } \\
\text { with diagnosed } \\
\text { respiratory or } \\
\text { circulatory sys- } \\
\text { tem diseases at } \\
\text { home }\end{array}$ \\
\hline Class 5 & Very high & $\begin{array}{l}\text { It is recommended } \\
\text { to minimise any } \\
\text { activities } \\
\text { outdoor, } \\
\text { especially if } \\
\text { they require } \\
\text { long-term or in- } \\
\text { tensified effort }\end{array}$ & $\begin{array}{l}\text { Children, elderly } \\
\text { persons, } \\
\text { pregnant } \\
\text { women and } \\
\text { persons with } \\
\text { diagnosed } \\
\text { respiratory or } \\
\text { circulatory } \\
\text { system diseases } \\
\text { should stay at } \\
\text { home }\end{array}$ \\
\hline
\end{tabular}

The maximum allowable concentration of $\mathrm{CO}$ in the air is $10,000 \mu \mathrm{g} / \mathrm{m}^{3}$ (J. Laws 2012, No.217, item 1031). In the outdoor air, $\mathrm{CO}$ concentration is ca. $300-350 \mathrm{ppm}$ in cities and $400 \mathrm{ppm}$ in industrial areas. Pursuant to the Regulation (Journal of Laws (2002b), no. 217, item 1833 , threshold limit value (TLV) of carbon oxide in the working environment is $23 \mu \mathrm{g} / \mathrm{m}^{3}$ and short-term $\mathrm{TLV}$ is $117 \mu \mathrm{g} / \mathrm{m}^{3}$. Furthermore, in Poland, the maximum allowable carbon oxide level in the outdoor air is $10,000 \mu \mathrm{g} / \mathrm{m}^{3}$ (Journal of Laws, No. 87, item 796) (measurement result averaging time $-8 \mathrm{~h}$ ) and in the indoor air of health service, its concentration should not exceed $30 \mu \mathrm{g} / \mathrm{m}^{3}$ within $24 \mathrm{~h}$ and $100 \mu \mathrm{g} / \mathrm{m}^{3}$ within $30 \mathrm{~min}$ (J. Laws 2008, No.47, item 281) (Table 2).

The EC Directive 2008/50/EC on ambient air quality (EC, 2008) limits air pollution to levels that minimise its adverse effects on population health and environment. It determines the quality standards of ambient air (i.e. threshold values that cannot be exceeded in the territory of EU) as regards the main air pollutants, (sulphur dioxide, nitrogen dioxide, nitrogen oxides, particulate matter, lead, benzene, carbon oxide and ozone) regulated by the Directive 1999/30/EC (EC,1999). Member states are obliged do indicate zones and urban areas for ambient air quality assessment and management, long-term tendency monitoring and making this information public. Where air quality is good, it is to be kept; where threshold values have been exceeded, proper action is to be taken. This directive is the first to include the objective related to air quality concerning particulate matter $\left(\mathrm{PM}_{2.5}\right)$.

$\mathrm{NO}_{2}, \mathrm{CO}$ and $\mathrm{PM}$ exposure reduction targets for the protection of human health are included also in several WHO documents and guidelines (WHO 1987, 2000, 2006, 2012, 2013) (Table 3).

The air quality has significantly improved since guidelines started to be introduced in the European Community in the 1970s. EU has got three various legal mechanisms at its disposal that makes it possible to limit air pollution. Those are as follows: determining general air quality standards concerning the concentration of pollutants in the atmospheric air, determining state threshold values of joint pollutant emission and preparing legislation concerning specific sources of pollution, e.g. 
Table 2 The methods of indexing, averaging times and the intervals of air pollutant concentrations of air quality index for Silesian Voivodship. The maximum allowable and alarm concentrations for $\mathrm{NO}_{2}$ and $\mathrm{CO}$ in air

\begin{tabular}{lll}
\hline Air quality index & The concentration of $\mathrm{NO}_{2}\left(\mu \mathrm{g} / \mathrm{m}^{3}\right)$ & The concentration of CO $\left(\mu \mathrm{g} / \mathrm{m}^{3}\right)$ \\
\hline & Averaging times & Averaging times \\
& $1 \mathrm{~h}$ & $0-\mathrm{h}$ moving average \\
Class 1 & $0-50$ & $0-5000$ \\
Very low & $51-100$ & $5000-7500$ \\
Class 2 & $101-200$ & $7500-10,000$ \\
Low & $200-400$ & $10,000-20,000$ \\
Class 3 & $>400$ & $>20,000$ \\
Average & $1 \mathrm{~h}-200$ & $8 \mathrm{~h}-10,000$ \\
Class 4 & $1 \mathrm{year}-40$ & - \\
High & $1 \mathrm{~h}-400$ &
\end{tabular}

legislation on industrial emission control or on determination of standards concerning pollutant emission by vehicles, efficient energy use or fuel quality. This legislation is supplemented by strategies and measures allowing for promotion of environment protection and their inclusion in the transport and energy sector. A range of directives were adopted in order to limit pollution caused by road transport by way of determination of emission standards for various vehicle categories, e.g. passenger cars, light commercial vehicles, lorries, buses and motorcycles, and regulation of fuel quality. While $\mathrm{CO}_{2}$ emissions from new cars and vans are being successfully reduced under recent EU legislation, the heavy-duty vehicles (HDV) strategy, adopted in May 2014 (EU, 2014), is the EU's

Table 3 Air pollutants concentrations and national and European standards (in $\mu \mathrm{g} / \mathrm{m}^{3}$ ), based on WHO reports

\begin{tabular}{|c|c|c|c|c|c|c|c|c|}
\hline Air pollutant & Time & WHO & EPA & EU & Poland & France & Germany & Great Britain \\
\hline \multirow[t]{6}{*}{$\mathrm{CO}$} & $10-15 \mathrm{~min}$ & 100.000 & - & - & - & - & - & - \\
\hline & $30 \mathrm{~min}$ & 60,000 & - & - & - & - & - & - \\
\hline & $1 \mathrm{~h}$ & 30,000 & 40,000 & - & - & - & - & - \\
\hline & $8 \mathrm{~h}$ & 10,000 & 10,000 & 10,000 & 10,000 & 10,000 & 10,000 & 10,000 \\
\hline & $24 \mathrm{~h}$ & - & - & - & - & - & - & - \\
\hline & Year & - & - & - & - & - & - & - \\
\hline \multirow[t]{4}{*}{$\mathrm{NO}_{2}$} & $30 \mathrm{~min}$ & - & - & - & - & - & 200 & - \\
\hline & $1 \mathrm{~h}$ & 200 & - & $\begin{array}{l}200 \\
\text { can be } \\
\text { exceeded } \\
\text { up to } 18 \\
\text { times per year }\end{array}$ & $\begin{array}{l}200 \\
\text { can be exceeded } \\
\text { up to } 18 \\
\text { times per year }\end{array}$ & $\begin{array}{l}230 \\
\text { no longer than } 0.2 \% \text { of time }\end{array}$ & - & $\begin{array}{l}200 \\
\text { can be } \\
\text { exceeded } \\
\text { up to } 18 \\
\text { times per year }\end{array}$ \\
\hline & $24 \mathrm{~h}$ & - & - & - & - & - & 100 & - \\
\hline & Year & 40 & 100 & 40 & 40 & 46 & - & 40 \\
\hline
\end{tabular}


first initiative to tackle such emissions from trucks, buses and coaches.

\section{Description of location of selected roads}

The measurements were made in two stations located by the A4 motorway, in a section running near the city centre. The A4 motorway is a Polish section of international road E40 and E462 extending the German A4 motorway from Drezno; it runs across South Poland, from the border with Germany to a border checkpoint with Ukraine. In the territory of the Upper Silesian urban area, there are two key hubs: GliwiceSośnica, where A4 crosses the A1 motorway, and Katowice-Murckowska hub in Katowice, which connects the A4 motorway (Górnośląska Avenue) and national road no. 86. It has to be pointed out that A4 concentrates the transit and local traffic of a city of over 300000 inhabitants and the Upper Silesian urban area of 5 million. The highway traffic intensity is 100,983100983 vehicles per day (General Director for National Roads and Motorways, 2015).

ext measurements were made in a station located by national road no. 86 , which runs through the city centre as well. National road no. 86 is the so-called fast traffic road. It connects the transit traffic between Katowice and Lódź and Warsaw and the local traffic as it runs through the centre of Częstochowa - a city of ca. 240 thousand. It is about $40 \mathrm{~km}$ long and is entirely located in the Silesian Voivodship. The expressway traffic intensity is 35 ,414 35414 vehicles per day (General Director for National Roads and Motorways, 2015). It is worth noting that the highway traffic intensity on both roads was similar to the same types of roads near big cities, in Germany, Netherlands or UK ( $30-150$ 30-150000 vehicles per day).
Description of measurement points

The measurements were carried out in three measurement stations belonging to the Voivodship Environmental Protection Inspectorate.

1. The first station was located in Chorzów Batory. Station type- communication. Monitoring type- automatic. Station type- stationary container. Distance from the nearest residential housing $(\mathrm{m})$ : 1000. Distance from the road (m): 7. The studies were conducted within the period from 2007/01/01 to $2010 / 12 / 07$; the station was active till December 2010. The station had to be close because of the change of the road layout.

2. The second station is located in Katowice, Górnośląska Avenue, and it has functioned since January 2011. The studies were conducted from 2011/01/08 to 2014/05/31. Prevalent emission source: communication, measurement type: automatic. Main emission sources: fuel combustion processes - road transport. $\mathrm{NO}_{2}$ measurement method: Chemiluminescence's. Measurement instrument: Environment S.A. Model AC32M NO Analyzer. $\mathrm{CO}$ measurement method: nondispersive infrared spectroscopy (NDIR). Measurement instrument: Environment S.A. Model CO12M CO Analyzer. Method equivalence: reference method. Sampling time - number: 1. unit: hour. Sampling interval - number: 1, unit: hour. Sampling height $(\mathrm{m}): 3.7$. Distance from the road (m): 10 .

3. The third station is located in Czestochowa, Armii Krajowej Street. The measurements were carried out from 2007/01/01 to 2014/05/31. Measurement type: automatic. The prevalent emission source has a communication background. Main emission sources: fuel combustion processes - road transport. $\mathrm{NO}_{2}$ measurement method: Chemiluminescence's. $\mathrm{NO}_{2}$ 
measuring instrument: Teledyne API T200 chemiluminescent NOx analyser. CO measurement method: non-dispersive infrared spectroscopy (NDIR). CO measuring instrument: Environment S.A. Model CO12M CO Analyzer. Method equivalence: reference method. Sampling time - number: 1, unit: hour. Sampling interval - number: 1. unit: hour. Sampling height $(\mathrm{m})$ : 3.7. Distance from the residential housing (m): 120. Distance from the road (m): 18 (Map 1).

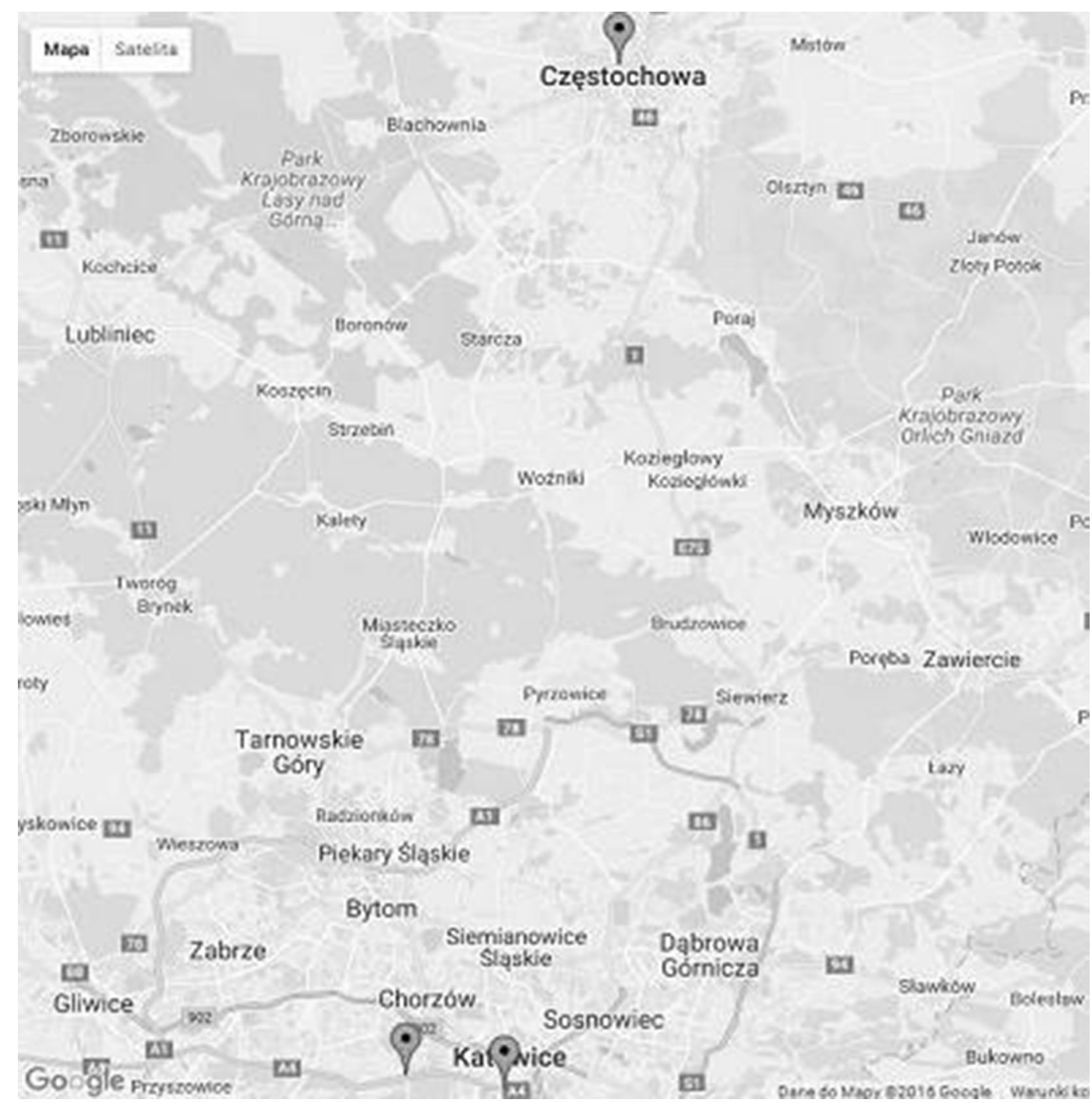

Map 1 Map of air pollution monitoring sites in Chorzów, Katowice and Częstochowa in the Upper Silesian agglomeration 
Nitrogen dioxide concentrations

\section{The first station- Chorzów Batory}

The dependence between the class of the air quality index (v. low and low) of average daily $\mathrm{NO}_{2}$ concentrations and year for the measured station was low (correlation ratio $\gamma=0.05$ ). The average daily $\mathrm{NO}_{2}$ concentrations measured at the station corresponded more frequently to class 1 (very low) than to class 2 (low): 60.9 and 39.1, 53.7 and 46.3 and 58.0 and $42.0 \%$ as well as 67.0 and $33.0 \%$, for year 2007, 2008, 2009 and 2010 , respectively.

\section{The second station- Katowice, Górnoślaska avenue}

The dependence between the class of the air quality index (v. low, low, medium) of average daily $\mathrm{NO}_{2}$ concentrations and year for the measured station was low (correlation ratio $\gamma=0.14$ ). $\mathrm{NO}_{2}$ concentrations corresponding to class 1 (very low) and 2 (low) were much more frequent than those corresponding to class 3 (medium): 31.8, 63.6 and 4.6; 56.6, 43.4 and 0.0 and $68.7,30.8$ and $0.6 \%$ as well as $34.4,59.6$ and $6.0 \%$, for year 2011, 2012, 2013 and 2014 (to May), respectively. No concentrations corresponding to class 4 (high) and 5 (very high) of the AQI were observed.

\section{The third station- Czestochowa, Armii Krajowej street}

The dependence between the average daily $\mathrm{NO}_{2}$ concentrations for the measured station and year was low (correlation ratio $\gamma=0.01$, Cramér's $V=0.1$ ). The value of the average daily $\mathrm{NO}_{2}$ concentrations measured at the station "very low" or "low" were much more frequent than "medium": 76.4, 23.0 and 0.6; 90.1, 9.9 and 0.0; $76.3,23.7$ and $0.0 ; 83.2,16.5$ and $0.3 ; 71.3,28.7$ and $0.0 ; 73.8,26.2$ and 0.0 and $81.0,19.0$ and $0.0 \%$ as well as $74.0,26.0$ and $0.0 \%$, for year 2007, 2008, 2009, 2010, 2011; 2012; 2013 and 2014 (to May), respectively. No concentrations corresponding to class 4 (high) and 5 (very high) were noted. The value of the AQI $-\mathrm{v}$. low-in relation to the average daily $\mathrm{NO}_{2}$ concentrations measured at the station, was most frequent for the year 2008: 76.4, 90.1, 76.3, 83.2, 71.3, 73.8, 81.0 and $74.0 \%$ for year 2007, 2008, 2009, 2010, 2011, 2012, 2013 and 2014 (to May), respectively. The value of the AQI - low - was most frequently observed for the year 2012: 23.0, 9.9, 23.7, 16.5, 28.7, 26.2, 19.0 and 26.0, whereas, the value of the AQI-medium - was most frequent for year 2007: 0.5, 0.0, 0.0, 0.3, 0.0, 0.0, 0.0 and $0.0 \%$ for year 2007, 2008, 2009, 2010, 2011, 2012, 2013 and 2014 (to May), respectively (Figs. 1 and 2).

No evidence was found of exceeding average daily values equal to the maximum allowable nitrogen dioxide concentration due to the protection of human health in the measurement area of all three stations.

Carbon monoxide concentrations

\section{The first station- Chorzów Batory}

The dependence between the average daily CO concentrations and year for the measured station was very low

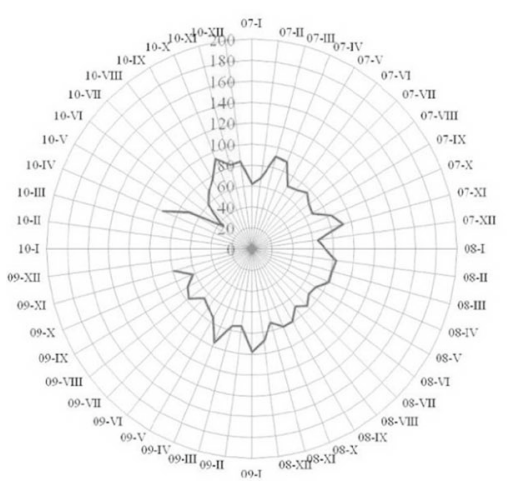

A - Chorzów Batory

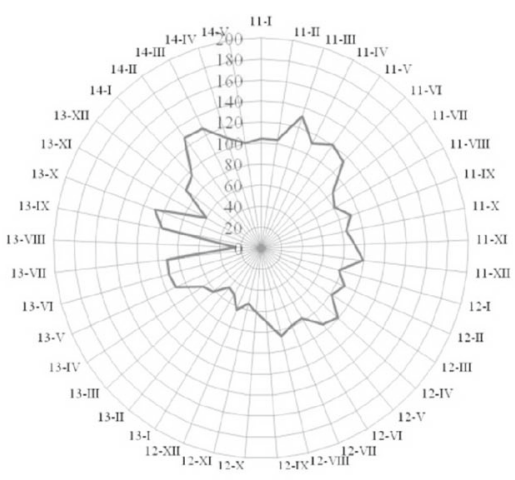

B - Katowice

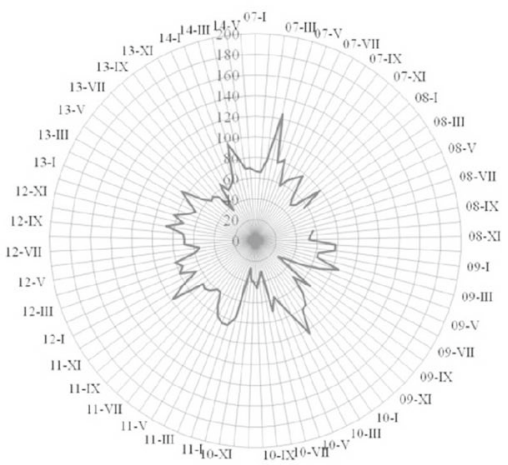

C - Częstochowa

Fig. 1 Radar chart of the highest values of the arithmetic means of $\mathrm{NO}_{2}\left(\mu \mathrm{g} / \mathrm{m}^{3}\right)$ per $24 \mathrm{~h}$ measured by the automatic stations of the State Environmental Monitoring located in Chorzów Batory, Katowice and Częstochowa 
The value of $\mathrm{NO}_{2}$ concentration
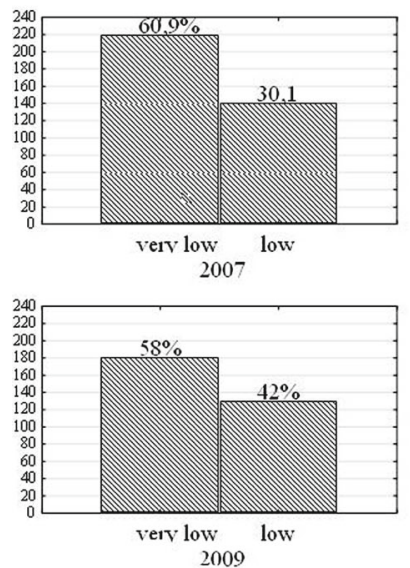

AIR OUALITY INDEX

A - Chorzów Batory
The value of $\mathrm{NO}_{2}$ concentration

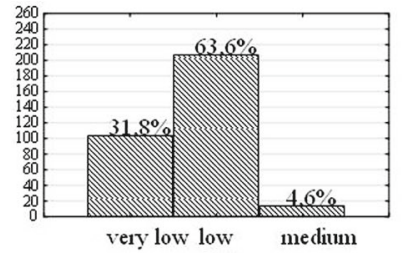

2

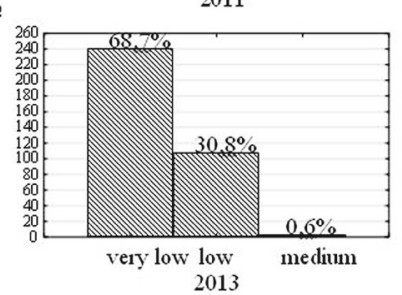

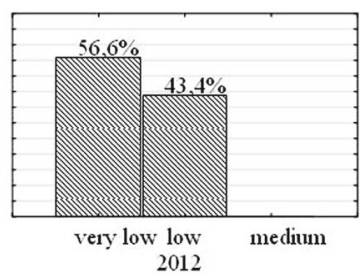

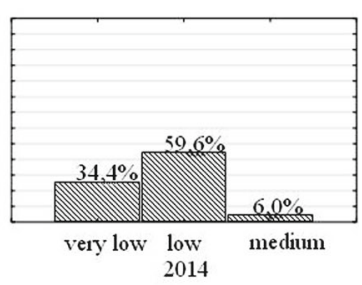

AIR QUALITY INDEX

The value of $\mathrm{NO}_{2}$ concentration
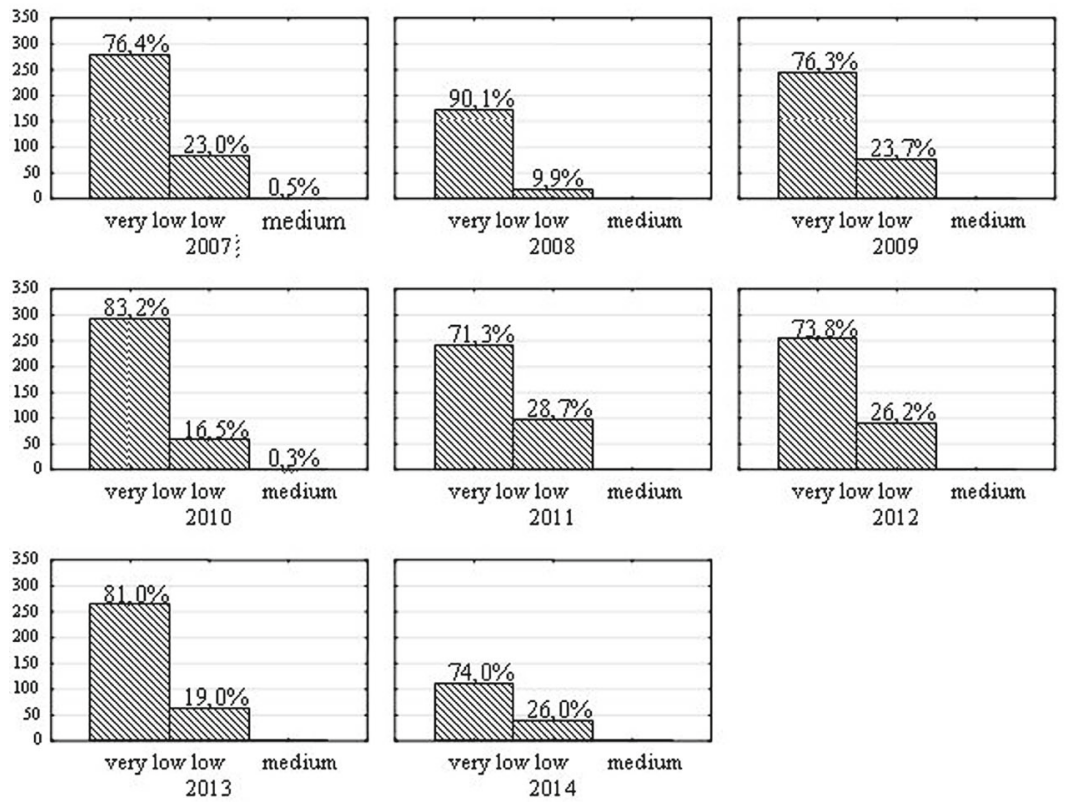

2012

AIR QUALITY INDEX

C - Częstochowa

Fig. 2 Histograms of empirical distributions of levels of air quality index to the arithmetic average values of $\mathrm{NO}_{2}$ per day measured in the automatic station of the State Environmental Monitoring in Chorzów Batory, Katowice and Czesstochowa

(Kendall's correlation ratio $\tau(\tau \mathrm{K})=0.01$ ). The values of average daily $\mathrm{CO}$ concentrations corresponded to class 1 (very low) of AQI below $1 \mathrm{mg} / \mathrm{m}^{3}$ were observed most frequently. No daily average values exceeding the maximum admissible $\mathrm{CO}$ concentration (8-h moving average) were noted in the examined period.

\section{The second station- Katowice, Górnoślaska avenue}

The dependence between the average daily CO concentrations and year was low (Kendall's correlation ratio $\tau(\tau \mathrm{K})=-0.13)$. The values of the average daily $\mathrm{CO}$ concentrations (for $8-\mathrm{h}$ arithmetic moving average) 
measured in the stations corresponded to class 1 (very low) of the AQI.

\section{The third station - Czestochowa, Armii Krajowej street}

The dependence between the average daily $\mathrm{CO}$ concentrations and year was very low (Kendall's correlation ratio $\tau(\tau \mathrm{K})=-0.04)$. The value of the of $\mathrm{CO}$ concentration for the 8-h moving average corresponded to class 1 (very low) of AQI. The received values of parameters and shapes of empirical distributions as well as created box-plot allow to state that the most frequent $\mathrm{CO}$ concentrations were values below $1.5 \mathrm{mg} / \mathrm{m}^{3}$ (Table 4 , Figs. 3 and 4).

The daily average values corresponding to the maximum admissible $\mathrm{CO}$ concentration (8-h arithmetic moving average) in relation to the protection of human health were not exceeded in the measurement zone of the stations.

\section{Discussion}

Transportation plays an important role in modern society, but its impact on air quality can have significant adverse effects on public health. Poland has experienced rapid motorization over the past 20 years, a trend that is likely to continue and a considerable development of road infrastructure, particularly in the recent decade; many new express roads and motorways, roads that run through city centres, ring roads and roads connecting cities were built. The growth in vehicles and the corresponding emissions create challenges to improving the urban air quality. Because many large neighbourhoods are located near heavy-traffic roads, it is essential to characterise near-road exposure to address concerns about public health and environmental justice. The construction of the new roads, especially like highways or expressways, very often led to large protests of local residents (i.e. the protest known as the Third Battle of Newbury some of the largest anti-road protests in
Table 4 The values of selected parameters of CO concentration (average daily concentration) measured by three automatic stations of the State Environmental Monitoring: in Chorzów Batory
Station (1); in Katowice, Górnoślasska Avenue Station (2) and in Częstochowa, Armii Krajowej Street Station (3)

\begin{tabular}{|c|c|c|c|c|c|c|c|c|c|}
\hline Year & $\mathrm{N}$ & $\mathrm{Me}$ & Min & Max & Q1 & Q3 & IQR & Vol. (\%) & As \\
\hline \multicolumn{10}{|c|}{ Station (1) } \\
\hline 2007 & 357 & 0.55 & 0.27 & 2.41 & 0.44 & 0.75 & 0.31 & 28.2 & 2.3 \\
\hline 2008 & 359 & 0.54 & 0.18 & 1.87 & 0.42 & 0.66 & 0.24 & 22.7 & 1.4 \\
\hline 2009 & 364 & 0.51 & 0.15 & 3.00 & 0.37 & 0.78 & 0.41 & 40.2 & 2.1 \\
\hline 2010 & 331 & 0.57 & 0.26 & 2.76 & 0.44 & 0.78 & 0.34 & 30.3 & 2.2 \\
\hline \multicolumn{10}{|c|}{ Station (2) } \\
\hline 2011 & 352 & 0.68 & 0.27 & 3.22 & 0.52 & 0.88 & 0.36 & 26.5 & 2.3 \\
\hline 2012 & 256 & 0.66 & 0.27 & 3.31 & 0.53 & 0.83 & 0.30 & 22.9 & 3.1 \\
\hline 2013 & 351 & 0.57 & 0.24 & 1.93 & 0.45 & 0.73 & 0.28 & 24.6 & 1.4 \\
\hline 2014 & 151 & 0.57 & 0.17 & 1.35 & 0.40 & 0.70 & 0.30 & 26.8 & 0.7 \\
\hline \multicolumn{10}{|c|}{ Station (3) } \\
\hline 2007 & 360 & 0.61 & 0.20 & 2.51 & 0.47 & 0.85 & 0.38 & 31.4 & 1.7 \\
\hline 2008 & 363 & 0.64 & 0.26 & 3.00 & 0.50 & 0.92 & 0.42 & 33.2 & 2.1 \\
\hline 2009 & 341 & 0.68 & 0.23 & 2.92 & 0.53 & 0.95 & 0.42 & 30.9 & 2.0 \\
\hline 2010 & 365 & 0.78 & 0.26 & 4.52 & 0.59 & 1.12 & 0.53 & 34.0 & 2.5 \\
\hline 2011 & 332 & 0.72 & 0.18 & 4.15 & 0.58 & 1.07 & 0.49 & 34.0 & 2.5 \\
\hline 2012 & 361 & 0.68 & 0.31 & 4.39 & 0.50 & 1.05 & 0.55 & 40.4 & 2.5 \\
\hline 2013 & 362 & 0.57 & 0.27 & 1.99 & 0.46 & 0.72 & 0.26 & 22.8 & 1.7 \\
\hline 2014 & 149 & 0.52 & 0.15 & 2.47 & 0.39 & 0.80 & 0.41 & 39.4 & 1.8 \\
\hline
\end{tabular}

$N$ the sample size of examined general population considering the study statistical feature. Me median, Min minimum value of statistical feature, Max maximum value of statistical feature, $Q 1$ lower quartile (the first), $Q 3$ upper quartile (the third), $I Q R$ quartile deviation; $V_{Q}(\%)$ coefficient variation, $Q=I Q R / 2$ quartile deviation, As skewness 


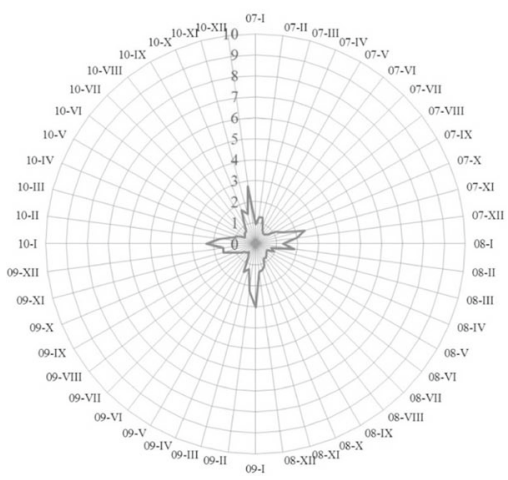

A - Chorzów Batory

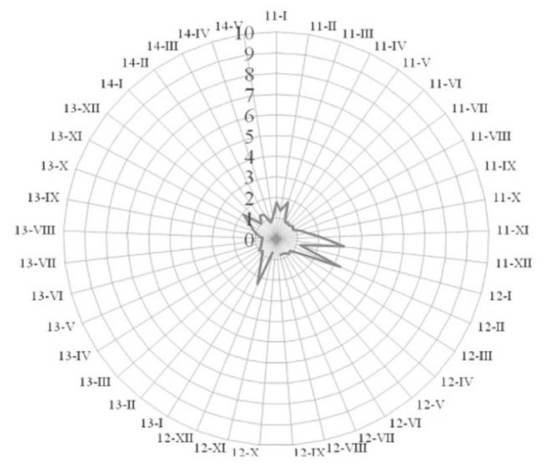

B - Katowice

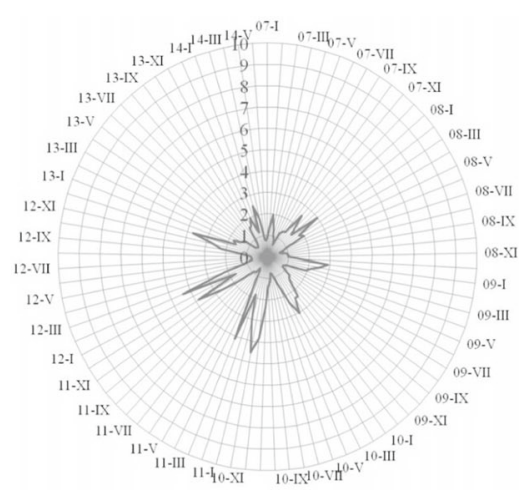

C - Częstochowa

Fig. 3 Radar chart of the highest values of the arithmetic means of CO $\left(\mathrm{mg} / \mathrm{m}^{3}\right)$ per $24 \mathrm{~h}$ measured by the automatic stations of the State Environmental Monitoring located in Chorzów Batory, Katowice and Częstochowa

Box and whisker plot of the values of the arithmetic means of $\mathrm{CO}\left(\mathrm{mg} / \mathrm{m}^{3}\right)$ per 24 hours measured by the automatic station of the State Environmental Monitoring located in Chorzow Batory,

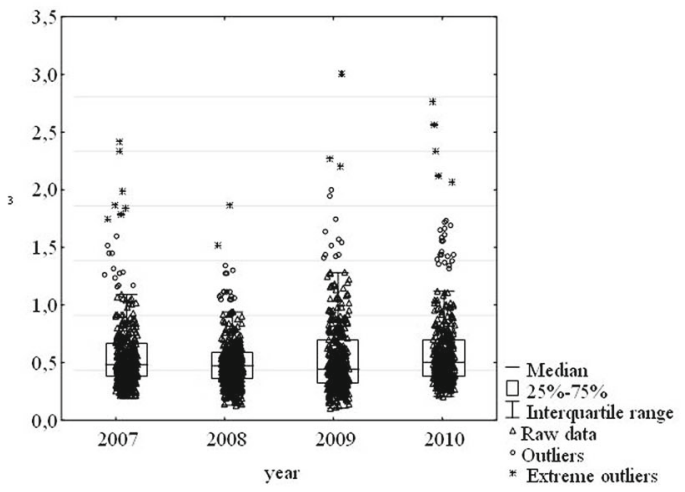

A - Chorzów Batory
Box and whisker plot of the values of the arithmetic means of $\mathrm{CO}\left(\mathrm{mg} / \mathrm{m}^{3}\right)$ per 24 hours measured by the automatic station of the State Environmental Monitoring located in Katowice

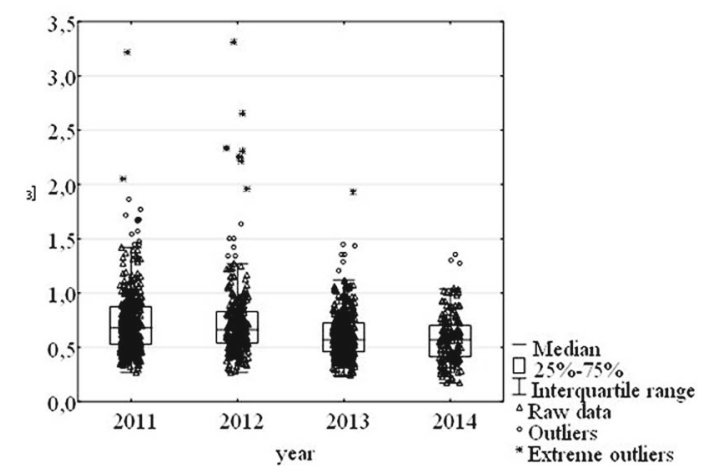

B - Katowice

Box and whisker plot of the values of the arithmetic means of $\mathrm{CO}\left(\mathrm{mg} / \mathrm{m}^{3}\right)$ per 24 hours measured by the automatic station of the State Environmental Monitoring located in Częstochowa

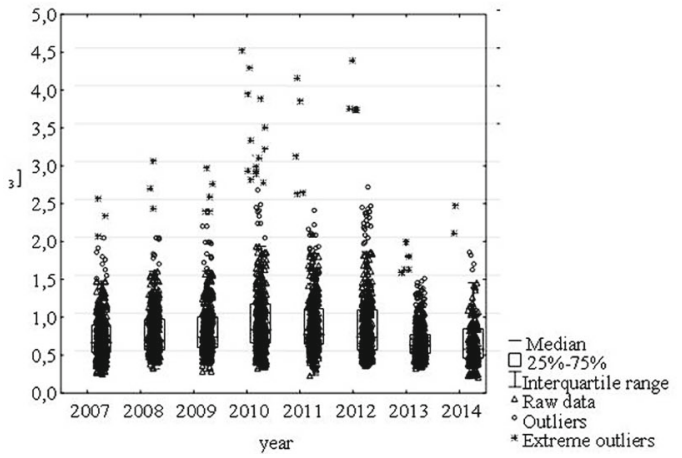

\section{C - Częstochowa}

Fig. 4 Box and whisker plot of the values of the arithmetic means of $\mathrm{CO}\left(\mathrm{mg} / \mathrm{m}^{3}\right)$ per $24 \mathrm{~h}$ measured by the automatic station of the State Environmental Monitoring located in Chorzów Batory, Katowice and Częstochowa 
European history, where around 7000 people demonstrated on the site of the bypass route and over 800 arrests being made, or the M11 link road protest was another major anti-road protest in Leytonstone, London, United Kingdom, in the early to mid-90s opposing the construction of the "A12 Hackney to M11 link road", which was part of a significant local road scheme to connect traffic avoiding urban streets). It is worth noting that the development of both roads presented in this study was also accompanied with numerous protests of local communities. One of the arguments of the residents of a housing estate, located near A4, against the development of a new road was that they were most afraid of increased noise and pollution connected with high-density traffic. That is why, providing evidencebased information, which could serve policy-makers and also be accessible by the media and the general public, seems to be very important.

In an effort to reduce the impact of vehicle emissions on urban air quality, Poland has adopted a number of vehicle emission control strategies and policies over the last decades. These strategies and policies include adopting a series of European emission standards. These are classified into seven categories: emission control on new vehicles, emission control on in-use vehicles, fuel quality improvements, alternative fuel and advanced vehicles, economic policies, public transport and temporal traffic control measures. Many have proven to be successful, such as the Euro emission standards, unleaded gasoline and low sulphur fuel. In general, the adoption of stringent vehicle emission standards requires simultaneous fuel quality improvements. A close relationship between fuel quality and vehicle emissions has been confirmed by several studies (Wu et al., 2011). This is also expected due to newer vehicle technologies (Roy et al., 2009) introduced to meet new stringent regulations. Thanks to the emission standards for new vehicles as well as other controls, the fleet-average emission rates of $\mathrm{CO}, \mathrm{NO}_{2}$ and $\mathrm{PM}_{10}$, by each major vehicle category, are decreasing over time.

\section{Conclusion}

It is well known that motor vehicle exhaust is a significant source of air pollution and the most widely reported pollutants in vehicular exhaust include carbon monoxide and nitrogen oxide. While the evidence is considerable, it is not overwhelming and is weak in some areas; our study gives such an example. The results clearly indicate lack of hazards for general population health in terms of increased concentrations of $\mathrm{CO}$ and $\mathrm{NO}_{2}$ compounds that are closely related to high intensity car traffic found on selected motorways and speedways located near the city centres.

Open Access This article is distributed under the terms of the Creative Commons Attribution 4.0 International License (http:// creativecommons.org/licenses/by/4.0/), which permits unrestricted use, distribution, and reproduction in any medium, provided you give appropriate credit to the original author(s) and the source, provide a link to the Creative Commons license, and indicate if changes were made.

\section{References}

Anderson, H. R. (2009). Air pollution and mortality: a history. Atmospheric Environment, 43, 142-152. doi:10.1016/j. atmosenv.2008.09.026.

Bérard, E., Bongard, V., Dallongeville, J., Arveiler, D., Amouyel, P., Wagner, A., Cottel, D., Haas, B., Ferrieres, J., \& Ruidavets, J. B. (2015). Expired-air carbon monoxide as a predictor of 16-year risk of all-cause, cardiovascular and cancer mortality. Preventive Medicine, 81, 195-201. doi:10.1016/j.ypmed.2015.09.001.

Chang, L. T., Chuang, K. J., Yang, W. T., Wang, V. S., Chuang, H. C., Bao, B. Y., Liu, C. S., \& Chang, T. Y. (2015). Short-term exposure to noise, fine particulate matter and nitrogen oxides on ambulatory blood pressure: a repeated-measure study. Environmental Research, 140, 634-640. doi:10.1016/j. envres.2015.06.004.

De Jarnett, N., Yeager, R., Conklin, D. J., Lee, J., O’Toole, T. E., McCracken, J., Abplanalp, W., Srivastava, S., Riggs, D., \& Bhatnagar, A. (2015). Residential proximity to major roadways is associated with increased levels of AC133+ circulating angiogenic cells. Arteriosclerosis, Thrombosis, and Vascular Biology, 35(11), 2468-2477. doi:10.1161/ATVBAHA.115.305724.

Ekoportal (2016). [Cited May 8 2016]. Available from: http://archiwum.ekoportal.gov.pl/prawo_dokumenty strategiczne/ochrona_srodowiska_w_polsce_ zagadnienia/Powietrze/PodstawoweZanieczyszczeniaPowietrza. html. [In Polish].

Fecht, D., Hansell, A. L., Morley, D., Dajnak, D., Vienneau, D., Beevers, S., Toledano, M., Kelly, F., Anderson, H., \& Gulliver, J. (2016). Spatial and temporal associations of road traffic noise and air pollution in London: implications for epidemiological studies. Environment International, 88, 235-242. doi:10.1016/j.envint.2015.12.001.

Fenger, J. (2009). Air pollution in the last 50 years - from local to global. Atmospheric Environment, 43, 13-22. doi:10.1016/j. atmosenv.2008.09.061. 
Gan, W. Q., Koehoorn, M., Davies, H. W., Demers, P. A., Tamburic, L., \& Brauer, M. (2011). Long-term exposure to traffic-related air pollution and the risk of coronary heart disease hospitalization and mortality. Environmental Health Perspectives, 119(4), 501-507. doi:10.1289/ehp.1002511.

Khamutian, R., Najafi, F., Soltanian, M., Shokoohizadeh, M. J., Poorhaghighat, S., Dargahi, A., Sharafi, K., \& Afshari, A. (2015). The association between air pollution and weather conditions with increase in the number of admissions of asthmatic patients in emergency wards: a case study in Kermanshah. Medical Journal of the Islamic Republic of Iran, 29, 229.

Lanki, T., Hampel, R., Tiittanen, P., Andrich, S., Beelen, R., Brunekreef, B., Dratva, J., De Faire, U., Fuks, K., Hoffman, B., et al. (2015). Air pollution from road traffic and systemic inflammation in adults: a cross-sectional analysis in the European ESCAPE project. Environmental Health Perspectives. doi:10.1289/ehp.1408224.

Li, S., Guo, Y., \& Williams, G. (2016). Acute impact of hourly ambient air pollution on preterm birth. Environmental Health Perspectives. doi:10.1289/EHP200.

Lucking, A. J., Lundback, M., Mills, N. L., Faratian, D., Barath, S. L., Pourazar, J., Cassee, F., Donaldson, K., Boon, N., Badimon, J., et al. (2008). Diesel exhaust inhalation increases thrombus formation in man. European Heart Journal, 29(24), 3043-3051. doi:10.1093/eurheartj/ehn464.

Lundbäck, M., Mills, N. L., Lucking, A., Barath, S., Donaldson, K., Newby, D. E., Sandstrom, T., \& Blomberg, A. (2009). Experimental exposure to diesel exhaust increases arterial stiffness in man. Particle and Fibre Toxicology, 6, 7. doi:10.1186/1743-8977-6-7.

Männistö, T., Mendola, P., Liu, D., Leishear, K., Sherman, S., \& Laughon, S. K. (2015). Acute air pollution exposure and blood pressure at delivery among women with and without hypertension. American Journal of Hypertension, 28(1), 5872. doi:10.1093/ajh/hpu077.

Miller, M. R., Mills, N. L., \& Newby, D. E. (2015). Road repairs: does exposure to traffic affect mechanisms of vascular injury and repair? Arteriosclerosis, Thrombosis, and Vascular Biology, 35(11), 22662268. doi:10.1161/ATVBAHA.115.306414.

Mills, N. L. (2005). Diesel exhaust inhalation causes vascular dysfunction and impaired endogenous fibrinolysis. Circulation, 112(25), 3930-3936. doi:10.1161/CIRCULATIONAHA.105.588962.

Mills, N. L., Törnqvist, H., Gonzalez, M. C., Vink, E., Robinson, S. D., Söderberg, S., Boon, N. A., Donaldson, K., Sandstrom, T., Blomberg, A., \& Newby, D. E. (2007). Ischemic and thrombotic effects of dilute diesel-exhaust inhalation in men with coronary heart disease. The New England Journal of Medicine, 357(11), 1075-1082. doi:10.1056/NEJMoa066314.

Ostro, B., Roth, L., Malig, B., \& Marty, M. (2009). The effects of fine particle components on respiratory hospital admissions in children. Environmental Health Perspectives, 117(3), 475480. doi:10.1289/ehp.11848.

Pedersen, M., Stayner, L., Slama, R., Sørensen, M., Figueras, F., Nieuwenhuijsen, M. J., Raaschou-Nielsen, O., \& Dadvand, P. (2014). Ambient air pollution and pregnancy-induced hypertensive disorders: a systematic review and meta-analysis. Hypertension, 64(3), 494-500. doi:10.1161 /HYPERTENSIONAHA.114.03545.
Peretz, A., Sullivan, J. H., Leotta, D. F., Trenga, C., Sands, F. N., Allen, J., Carlsten, C., Wilkinson, C. W., Gill, E. A., \& Kaufman, J. D. (2008). Diesel exhaust inhalation elicits acute vasoconstriction in vivo. Environmental Health Perspectives, 116(7), 937-942. doi:10.1289/ehp.11027.

Qian, Z., Liang, S., Yang, S., Trevathan, E., Huang, Z., Yang, R., Wang, J., Hu, K., Zhang, Y., \& Zhang, B. (2016). Ambient air pollution and preterm birth: a prospective birth cohort study in Wuhan, China. International Journal of Hygiene and Environmental Health, 219(2), 195-203. doi:10.1016/j. ijheh.2015.11.003.

Roy, S., Hegde, M. S., \& Madras, G. (2009). Catalysis for NOx abatement. Applied Energy, 86, 2283-2297.

Samoli, E., Analitis, A., Touloumi, G., Schwartz, J., Anderson, H. R., \& Sunyer, J. (2005). Estimating the exposure-response relationship between particulate matter and mortality within the APHEA multicity project. Environmental Health Perspectives, 113, 88-95. doi:10.1289/ehp.7387.

Samoli, E., Atkinson, R. W., Analitis, A., Fuller, G. W., Green, D. C., Mudway, I., Anderson, H. R., \& Kelly, F. J. (2016). Associations of short-term exposure to traffic-related air pollution with cardiovascular and respiratory hospital admissions in London, UK. Occupational and Environmental Medicine, 73(5), 300-307. doi:10.1136/oemed-2015103136.

Sørensen, M., Hjortebjerg, D., Eriksen, K. T., Ketzel, M., Tjønneland, A., Overvad, K., \& Raaschou-Nielsen, O. (2015). Exposure to long-term air pollution and road traffic noise in relation to cholesterol: a cross-sectional study. Environment International, 85, 238-243. doi:10.1016/j. envint.2015.09.021.

Stat Soft. Int. (2011). Available from: https://www.statsoft. p1/textbook/stathome.html [in Polish]. Accessed 15 August 2014.

The Act of 22 June 2002 of admissible levels of certain substances in air, alarm levels of certain substances in air and margin of tolerance for the maximum levels of certain substances. J. Laws 2002a No. 87, item 796. [In Polish].

The Act of 29 November 2002 of maximum admissible levels of certain toxical substances in workplace J. Laws (2002b) No. 217, item 1833, as amended. [In Polish].

The Act of 3 March 2008 of levels of certain substances in air J. Laws (2008) No. 47, item 281. [In Polish].

The Act of 24 August 2012 of levels of certain substances in air. J. Laws (2012) No. 217, item 1031. [In Polish].

The European Commission (1999) Directive 1999/30/EC of 22 April 1999 relating to limit values for sulphur dioxide, nitrogen dioxide and oxides of nitrogen, particulate matter and lead in ambient air. Official Journal L 163, 29/06/1999 P. 0041-0060.

The European Commission (2008) Directive 2008/50/EC of the European Parliament and of the Council of 21 May 2008 on ambient air quality and cleaner air for Europe. Official Journal of the EU. OJ L 152, 11.6.2008, p. 1-44.

The European Commission (2014) Strategy for reducing HeavyDuty Vehicles' fuel consumption and CO2 emissions. 21 of May 2014. [Cited May 15, 2016]. Available from: https://ec.europa. $\mathrm{eu} / \mathrm{clima} /$ policies/transport/vehicles/heavy/docs/com_285_2014 en.pdf.

The General Director for National Roads and Motorways (2015) [Cited April 29, 2009]. Available from: https:/www.gddkia. gov.pl/pl/2551/GPR-2015 [in Polish]. 
The Government of Canada (2010) Environment and Climate Change Canada - Air - Nitrogen Oxides - NOx. [Citeded April 25, 2016]. Available from http://www.ec.gc. ca/air/default.asp?lang=En\&n=489FEE7D-1.

The World Health Organization (1987) Air quality guidelines for Europe. World Health Organization Regional Office for Europe. WHO Regional Publications, European Series, Copenhagen; No.23.

The World Health Organization (2000). Air quality guidelines for Europe. In Copenhagen, World Health Organization Regional Office for Europe (2nd ed.). Copenhagen: WHO Regional Publications, European Series No. 91.

The World Health Organization (2006). Air quality guidelines: global update 2005, particulate matter, ozone, nitrogen dioxide and sulfur dioxide. Copenhagen: WHO Regional Office for Europe.
The World Health Organization (2013) REVIHAAP Final technical report final version - REVIHAAP-Final-technical-report-finalversion.pdf. [Cited May 9, 2016]. Available from: http://www. euro.who.int/_data/assets/pdf_file/0004/193108 /REVIHAAP-Final-technical-report-final-version.pdf.

The World Health Organization. Environmental Indicator Report (2012) WHO European Environment Agency, Copenhagen.

Wu, Y., Wang, R., Zhou, Y., Lin, B., Fu, L., He, K., \& Hao, J. (2011). On-road vehicle emission control in Beijing: past, present, and future. Environmental Science and Technology, 45, 147-153.

Zheng, X., Ding, H., Jiang, L., Chen, S., Zheng, J., Qiu, M., Zhou, Y. X., Chen, Q., \& Guan, W. (2015). Association between air pollutants and asthma emergency room visits and hospital admissions in time series studies: a systematic review and meta-analysis. PloS One, 10(9), e0138146. doi:10.1371 /journal.pone.0138146. 